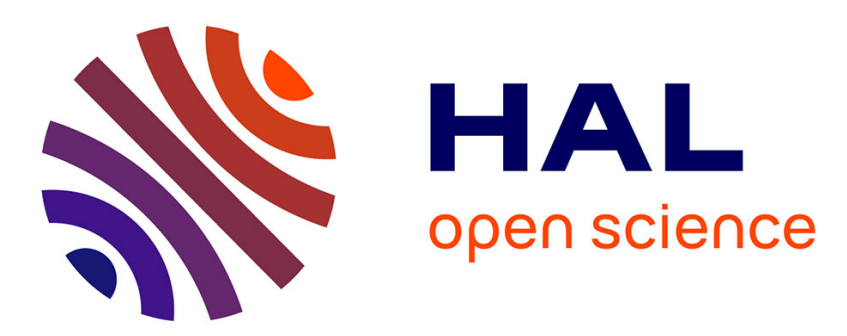

\title{
Cellular localization, accumulation and trafficking of double-walled carbon nanotubes in human prostate cancer cells
}

Vera Neves, Andreas Gerondopoulos, Elena Heister, Carmen Tîlmaciu, Emmanuel Flahaut, Brigitte Soula, S. Ravi P. Silva, Johnjoe Mcfadden, Helen M. Coley

\section{To cite this version:}

Vera Neves, Andreas Gerondopoulos, Elena Heister, Carmen Tîlmaciu, Emmanuel Flahaut, et al.. Cellular localization, accumulation and trafficking of double-walled carbon nanotubes in human prostate cancer cells. Nano Research, 2012, vol. 5, pp. 223-234. 10.1007/s12274-012-0202-9 . hal-00836017

\section{HAL Id: hal-00836017 https://hal.science/hal-00836017}

Submitted on 21 Jun 2013

HAL is a multi-disciplinary open access archive for the deposit and dissemination of scientific research documents, whether they are published or not. The documents may come from teaching and research institutions in France or abroad, or from public or private research centers.
L'archive ouverte pluridisciplinaire HAL, est destinée au dépôt et à la diffusion de documents scientifiques de niveau recherche, publiés ou non, émanant des établissements d'enseignement et de recherche français ou étrangers, des laboratoires publics ou privés. 


\section{OATAO \\ Open Archive Toulouse Archive Ouverte}

\section{Open Archive TOULOUSE Archive Ouverte (OATAO)}

OATAO is an open access repository that collects the work of Toulouse researchers and makes it freely available over the web where possible.

This is an author-deposited version published in : http://oatao.univ-toulouse.fr/ Eprints ID : 8713

To link to this article : http://dx.doi.org/10.1007/s12274-012-0202-9

To cite this version :

Neves, Vera and Gerondopoulos, Andreas and Heister, Elena and Tîlmaciu, Carmen and Flahaut, Emmanuel and Soula, Brigitte and Silva, S. Ravi P. and McFadden, Johnjoe and Coley, Helen M. Cellular localization, accumulation and trafficking of doublewalled carbon nanotubes in human prostate cancer cells. (2012) Nano Research, vol. 5 ( ${ }^{\circ}$ 4). pp. 223-234. ISSN 1998-0124

Any correspondance concerning this service should be sent to the repository administrator: staff-oatao@inp-toulouse.fr 


\title{
Cellular Localization, Accumulation and Trafficking of Double- Walled Carbon Nanotubes in Human Prostate Cancer Cells
}

\author{
Vera Neves $^{1,2}$, Andreas Gerondopoulos $^{1, \dagger}$, Elena Heister ${ }^{1,2}$, Carmen Tîlmaciu $^{3}$, Emmanuel Flahaut ${ }^{3}$, B. Soula ${ }^{3}$, \\ S. Ravi P. Silva ${ }^{2}$, and Johnjoe McFadden ${ }^{1}$, and Helen M. Coley $^{1}(\varangle)$ \\ ${ }^{1}$ Faculty of Health and Medical Sciences, University of Surrey, Guildford GU27XH, UK \\ ${ }^{2}$ Nanoelectronics Centre, Advanced Technology Institute, University of Surrey, Guildford GU27XH, UK \\ ${ }^{3}$ Université de Toulouse, UPS/INP/CNRS, Institut Carnot CIRIMAT, 118 route de Narbonne, 31062 Toulouse, Cedex 9, France \\ ${ }^{\dagger}$ Present address: Department of Biochemistry, University of Oxford, Oxford OX13QU, UK
}

\begin{abstract}
Carbon nanotubes (CNTs) are at present being considered as potential nanovectors with the ability to deliver therapeutic cargoes into living cells. Previous studies established the ability of CNTs to enter cells and their therapeutic utility, but an appreciation of global intracellular trafficking associated with their cellular distribution has yet to be described. Despite the many aspects of the uptake mechanism of CNTs being studied, only a few studies have investigated internalization and fate of CNTs inside cells in detail. In the present study, intracellular localization and trafficking of RNA-wrapped, oxidized double-walled CNTs (oxDWNT-RNA) is presented. Fixed cells, previously exposed to oxDWNT-RNA, were subjected to immunocytochemical analysis using antibodies specific to proteins implicated in endocytosis; moreover cell compartment markers and pharmacological inhibitory conditions were also employed in this study. Our results revealed that an endocytic pathway is involved in the internalization of oxDWNT-RNA. The nanotubes were found in clathrin-coated vesicles, after which they appear to be sorted in early endosomes, followed by vesicular maturation, become located in lysosomes. Furthermore, we observed co-localization of oxDWNT-RNA with the small GTP-binding protein (Rab 11), involved in their recycling back to the plasma membrane via endosomes from the trans-golgi network.
\end{abstract}

\section{KEYWORDS}

Double-walled carbon nanotubes (DWNTs), intracellular localization, uptake, immunostaining, inhibition of endocytosis

\section{Introduction}

The mechanisms that control cellular uptake and release of carbon nanotubes (CNTs) are currently poorly understood. So far, besides the demonstration of the ability of CNTs to enter and penetrate cell membranes [1-4], the uptake mechanism is still debated and may involve more than one process. Indeed, Kam et al. and Jin et al. reported that protein or single-stranded oligonucleotide-modified CNTs could enter cells by means of endocytosis [5, 6]. In contrast, Kostarelos et al. suggested that an energy-independent non-endocytic mechanism is involved in the insertion and diffusion of CNTs through different cellular barriers [2].

Address correspondence to H.Coley@surrey.ac.uk 
Endocytosis is a frequent cellular event that transfers extracellular or membrane-bound cargoes, such as nutrients, from the plasma membrane into the cell interior by vesicular transport. In this process, endocytic vesicles form invaginations of the plasma membrane that subsequently pinch off, move internally, and fuse with other endocytic vesicles to form the early endosomal compartment. The endocytic process may involve so-called clathrin-coated pits (i.e., associated with a clathrin-dependent process). Clathrin forms a complex network in the form of a lattice that is built up to form a coat. Alternatively, there may be clathrin-independent endocytotic processes involved in cellular trafficking. The early endosome is the major sorting station in the endocytic pathways. From this organelle, material can be directed toward the pathway of recycling to the plasma membrane, to subsequent endocytic compartments and to regulated secretory vesicles [7]. Transferrin for example, a monomeric iron transporting serum glycoprotein, is processed in the late endosome, after which the transferrin receptors are recycled by a recycling endosome [8]. The recycling endosome is typically less acidic ( $\mathrm{pH}$ 6.4-6.5) than the sorting endosome $(\mathrm{pH}$ 6.0) and exhibits a pericentriolar localization [9]. Late endosomes contain active degradative enzymes; however, these are more concentrated in the lysosomes. The transfer of material between late endosomes and lysosomes appears to be a direct fusion event that results in a transient hybrid organelle [10].

Each step in endocytosis is independently regulated by the interaction of multiple proteins. These include several small GTP-binding proteins of the Rab family. These proteins have been particularly examined because of their effectiveness as molecular markers for various types of endosomes. Rab 5, an example of such GTPase-associated activity [11], regulates the rate of clathrin-dependent endocytosis at the plasma membrane and can be used as a marker for early sorting endosomes in addition to or in conjunction with the transferrin receptor. Rab 11 localizes to a pericentriolar subpopulation of recycling endosomes [12]. It is pertinent to point out that the process of endocytosis is a complex process that has yet to be completely defined despite significant progress in understanding its various components.
Identification of the mode by which CNTs move between cellular compartments after their internalization, and the sites in which they localize has been thus far been accomplished by simple staining of lysosomes by $\mathrm{pH}$-dependent markers (e.g., LysoTracker ${ }^{\circledR}$ red) $[5,13]$, by transmission electron microscopy (TEM) [13-15], or by pharmacological inhibition of the endocytic pathway [2,5]. Kam et al. [5] were the first to describe an energy-dependent mechanism. In their studies, clathrin-mediated endocytosis was proven by experiments carried out under inhibitory conditions, such as the presence of sucrose and a potassium-depleted medium, which revealed a significantly reduced level of CNT uptake. Using TEM, Yehia et al. 2007 observed that singlewalled carbon nanotubes (SWNTs) dispersed in medium were endocytosed and localized in the plasma membrane, cytoplasm, endosomes, lysosomes, and golgi bodies [16]. A similar methodology was used by Mu et al. 2009, who proposed a working model for cell uptake of multi-walled carbon nanotubes (MWNTs) modified by carboxylation or amidation, using TEM imaging [15]. In their model, CNTs were not only internalized via endocytic pathways, but also through membrane penetration, depending on whether CNTs were present as bundles or highly dispersed single CNTs, respectively [15]. After both internalization via endocytosis or membrane penetration, CNTs were found in lysosomes, followed by their extrusion [15]. However, no data were presented on the mechanism of exocytosis. In 2009, Jin et al. presented the first evidence for exocytosis of CNTs, which was found to closely match the endocytic rate [13]. Furthermore, a study in our group demonstrated the time-dependent loss of CNTs by cells [4].

In contrast to the endocytic pathway, Lacerda et al. reported for the first time that membrane penetration of CNTs (SWNTs modified via cycloaddition) can lead to their accumulation in the perinuclear region of mammalian cells [17]. In addition, another study performed by Zhou et al. in 2010 also showed an endocytosis-independent mechanism for non-covalently modified SWNTs [18]. In their studies, incubations at $4{ }^{\circ} \mathrm{C}$ and in the presence of sodium azide $\left(\mathrm{NaN}_{3}\right)$ were carried out, which failed to prevent CNTs from being internalized. 
In spite of the considerable effort to elucidate the uptake mechanism of CNTs and their intracellular localization, an appreciation of global intracellular trafficking has yet to be clarified. Herein we attempt to complete this study using organelle-specific markers to describe and to identify the mechanisms through which CNTs are transported as they enter and eventually efflux from in vitro-cultured human prostate cancer cells.

\section{Results and discussion}

Double-walled carbon nanotube (DWNT) cellular uptake and release has been previously demonstrated by our group using Raman spectroscopy [4]. However, it is also imperative to understand their intracellular route and subcellular localizations during their transit through cells. Hence, this study presents a detailed methodology using confocal microscopy in combination with organelle-specific markers to examine the intracellular distribution of CNTs. In addition, pathway-inhibitory drugs were used to identify major processes through which CNTs traffic as they enter and eventually efflux from cells. For this purpose, fluorescently labelled RNA-wrapped oxidized DWNTs (oxDWNTs) were employed.

\subsection{Characterization of CNT complexes}

CNT complexes were characterized using microscopic techniques, in particular atomic force microscopy (AFM) and TEM. Figure 1(a) depicts an AFM scan over a surface of fluorescein-RNA-wrapped oxidized DWNTs (oxDWNT-RNA-FS). Furthermore, the TEM image in Fig. 1(b) depicts individualized CNTs with noticeable two-wall characteristics of the DWNTs.

Raman spectroscopy is a useful tool for the identification of CNTs in a sample, since they have characteristic Raman features. Figure 1(c) shows the Raman spectra of pristine DWNTs and oxDWNTRNA-FSs. The first visible peaks are the radial breathing modes (RBMs), caused by uniaxial vibrations, which depend linearly on the nanotube diameter; these can be found between $150-300 \mathrm{~cm}^{-1}$. The RBM is then followed by the disorder-induced D-band between 1250 and $1450 \mathrm{~cm}^{-1}$, the tangential mode (or
G-band), which is caused by stretching along the C-C bonds, between 1590-1600 $\mathrm{cm}^{-1}$ [19-21], and finally the $\mathrm{G}^{\prime}$-band, a two-phonon mode $\sim 2700 \mathrm{~cm}^{-1}$ away from the excitation wavelength [19]. The spectra in Fig. 1(c) demonstrate that the D-band intensity increases during the oxidation process; nevertheless the $D / G$ ratio is overall still rather low due to the preservation of the structure of the inner tube.

Figure 1(d) exhibits the Raman signal of cells exposed to oxDWNT-RNA-FS and cells as a control. To determine if cells internalized the full complex of oxDWNTs, RNA, and fluorescein, the same slides that

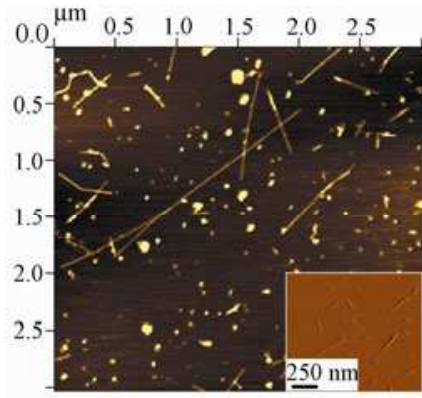

(a)

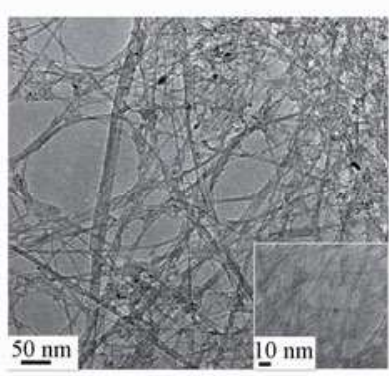

(b)

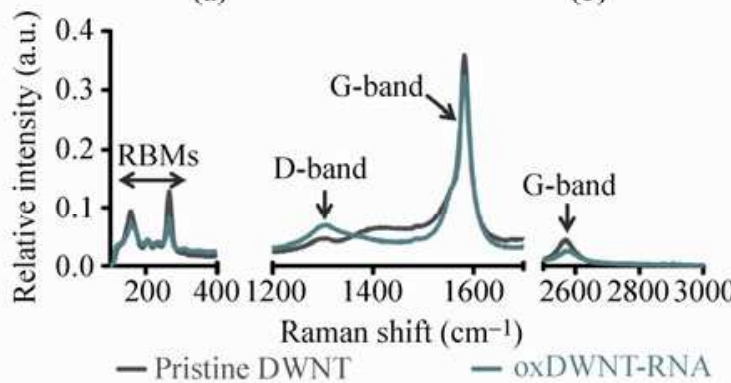

(c)

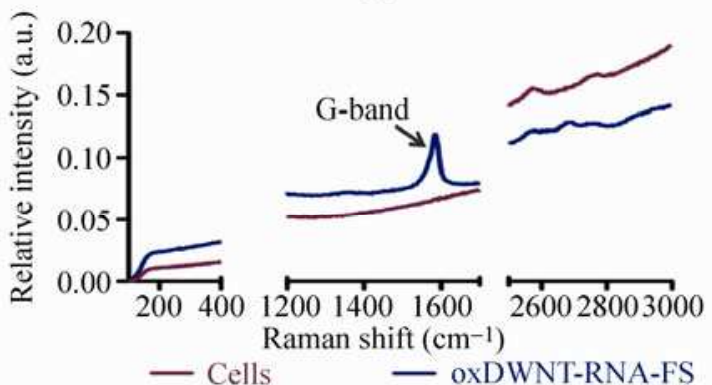

(d)

Figure 1 Characterization of CNT complexes. AFM (a) and TEM (b) images of fluorescently labelled RNA-wrapped oxidized DWNTs (oxDWNT-RNA-FS). (c) Raman spectra of pristine DWNTs and oxDWNT-RNA-FS. The ratio D/G band has increased for oxDWNT-RNA-FS samples due to acid ox idation. (d) Raman spectroscopy of cells exposed to oxDWNT-RNA-FS and control (cells only) 
were used for fluorescence microscopy were used for Raman spectroscopy. The results (Fig. 1(d)) show that the G-band, which is a characteristic signature band for CNTs, can be clearly observed in the Raman spectrum of cells exposed to oxDWNT-RNA-FS, thus confirming successful cellular uptake. Furthermore, we have shown in an independent study by our group based on Raman spectroscopy that RNA-wrapped oxidized DWNTs are internalized and released by cells in a time-dependent manner [4]. In particular, cells were exposed to CNTs for $3 \mathrm{~h}$, corresponding with maximal intake, after which CNTs were removed from the surrounding medium and the release of CNTs from the cells monitored for further $21 \mathrm{~h}$. The study showed that CNTs were released progressively over this time frame up until the end point of the experiment $(24 \mathrm{~h})$, when no CNT-signal could be measured any longer inside the cells [4].

The stability of oxidized and RNA-wrapped CNTs in biological fluids, as well as their cytotoxicity, has also been previously examined in our group [22]. In that study it was shown that oxidized CNTs are relatively stable in cellular growth medium and that additional wrapping with RNA further increased their stability in human plasma. Moreover, it was found that cells incubated with oxidized, RNA-wrapped CNTs were 75\% viable [22]. Although RNA-wrapping is potentially prone to degradation in cellular growth medium or the cell interior, it was demonstrated by others that siRNA-wrapped CNTs readily enter cells and that the siRNA remains biologically active in the cell even in the presence of serum [23], which is very likely due to the fact that CNTs can protect singlestranded nucleic acids from enzymatic cleavage and intracellular interference from nucleic acid binding proteins [24].

\subsection{Cellular internalization of CNT complexes}

Confocal microscopy was used to demonstrate the internalization of fluorescently labelled CNTs. PC3 human prostate cancer cells were incubated with $30 \mu \mathrm{g} / \mathrm{mL}$ of oxDWNT-RNA-FS for $2 \mathrm{~h}$. This incubation period was chosen based on previous papers on endoand exocytosis of carbon nanotubes, for example by
Jin et al., who observed maximal cellular uptake of CNTs between $1 \mathrm{~h}$ and $2 \mathrm{~h}$ [13]. Subsequently, cells were fixed to prevent morphologic changes and inhibit further natural cellular transport, which "traps" CNTs in the various cellular compartments, in which they are located at the time. This provides a snapshot of the intracellular distribution of CNTs after internalization and release have reached a steady state: while some CNTs are just being internalized, others are already being sorted in lysosomes, or even exocytosed.

Figure 2 reveals that incubation of PC3 human prostate cancer cells with oxDWNT-RNA-FS produced readily detectable fluorescence in the cytoplasm (green) in the same plane as the nucleus, but not in the nucleus itself (counterstained in blue). The cytoskeleton, which is involved in coordinating the organization and dynamics of intracellular architecture and therefore relevant to the further understanding of membrane trafficking was stained with phalloidin (red). Cell morphology appeared regular after exposure to CNTs and inhibitory drugs, and no obvious signs of artefactual cellular damage or associated toxicity with the procedures used throughout this work were observed.

To determine the cellular compartments in which CNT complexes localize and traffic between, organellespecific antibodies were employed. After fixation to prevent morphological changes, cells were incubated with primary antibodies specific to certain proteins (e.g., clathrin) and then a fluorescently labeled secondary antibody was employed specific to the source of the primary antibody (e.g., rabbit).

The internalization via the endocytic route involves a cascade of intracellular events, with different vesicles and regulators. The observation of CNT complexes in intracellular endosome-like structures (Fig. 2) suggested that an endocytic pathway was involved in the internalization of the complexes. Therefore, it was decided to use markers such as clathrin and caveolin involved in the first step of endocytosis, invagination of the cell membrane, to elucidate which endocytosis mechanism in particular is responsible for CNT uptake. Clathrin-mediated endocytosis is characterized by membrane-bound vesicles inside a coat composed 
primarily of the fibrous protein clathrin. In contrast, caveolae are plasma membrane invaginations that are enriched in cholesterol and sphingolipids. In addition, these invaginations also accumulate special cholesterol-binding proteins, termed caveolins, on the cytosolic face of vesicles [25-28]. Certain ligands, which are internalized via caveolae, are likely to be delivered to a special endosomal compartment referred to as a "caveosome" [29]. Caveosomes containing caveolins do not transport/co-localize transferrin, lack EEA1 and other early endosomal markers, have neutral $\mathrm{pH}$, and can act as sorting stations [26]. Figure 2(c) shows co-localization of the CNT complexes (green) with clathrin (red); but no co-localization with caveolin (Fig. 2(b)).

Generally, newly formed plasma membrane-derived endocytic vesicles lose their clathrin coat and fuse with each other or with pre-existing compartments known as sorting endosomes [30,31]. The first endosomal compartment, the sorting or early endosome, has a role in sorting the cargo for further transport. The early endosome can be identified using an early endosome antigen (EEA1) in combination with a fluorescent secondary antibody. Our data show that CNT complexes are closely associated with this location, as seen via co-localization studies of CNT complexes (green) with EEA1 (red) (Fig. 2(d)).

The drop in the $\mathrm{pH}$ within the sorting endosome dissociates many ligands from their receptor, allowing those receptors to be recycled back to the plasma membrane. As previously described, small GTPases have emerged as central regulators of vesicle budding, motility, and fusion. One of these proteins is Rab 4, involved in the recycling back to the plasma membrane from the early endosome. However, our results suggest that Rab 4 does not have a function in the trafficking of CNT complexes through the cell, as no co-localization was observed (Fig. 2(e)).

Maturation of sorting endosomes into late endosomes or multivesicular bodies is coincidental with a drop of the $\mathrm{pH}$. The endosome becomes incapable to commit further fusion with vesicles from the cell surface or other sorting endosomes, thus preventing new cargoes and receptors from being inadvertently degraded by 'joining' a late endosome as it matures into/fuses with a lysosome [27]. The lysosome can be identified using antibodies for lysosome membrane proteins (LMP). LMPs reside mainly in the lysosomal limiting membrane and have diverse functions, including acidification of the lysosomal lumen, protein import from the cytosol, membrane fusion and transport of degradation products to the cytoplasm. The most abundant LMPs are the lysosome-associated membrane protein 1 (LAMP1), LAMP2, lysosomal integral membrane protein 2 (LIMP2) and the tetraspanin CD63 [28]. As demonstrated in Fig. 2(f), a high level of co-localization was observed with LAMP2 (selected for our co-localization studies), thus indicating that CNT complexes end up in the lysosomes after being endocytosed.

The recycling endosome not only allows for the recycling of plasma membrane components (a branch of the pathway that might need to be avoided in the context of drug delivery) but also enables the cell to traffic molecules back to the trans-golgi network (TGN/Golgi) [29]. Again, Rab proteins have been found to regulate this transport, especially the Rab 11 GTPase complex. Figure 2(g) shows co-localization of Rab 11 and the CNT complexes, indicating that they reach the vesicles from the secretory pathway and are delivered by Rab 11-positive vesicles. The trans-golgi trafficking, in which Rab 11 is involved may be further validated using antibodies for the golgi97 protein, which localizes on the trans side of the golgi apparatus. It is believed to participate in the trafficking of vesicles between the golgi stacks and the trans-golgi network [32]. This additional analysis, however, exceeded the scope of this paper.

In addition to co-localization with a clathrin-specific antibody, CNT complexes also co-localized with transferrin (Fig. 2(h)). Transferrin is a monomeric serum glycoprotein that binds iron. After its recognition at the cell surface by transferrin receptors, transferrin is internalized via clathrin-dependent endocytosis. Inside endosomes, the acidic environment favours dissociation of iron from the transferrin. After sorting in late endosomes, transferrin then reaches the golgi apparatus and is subsequently recycled back to the plasma 

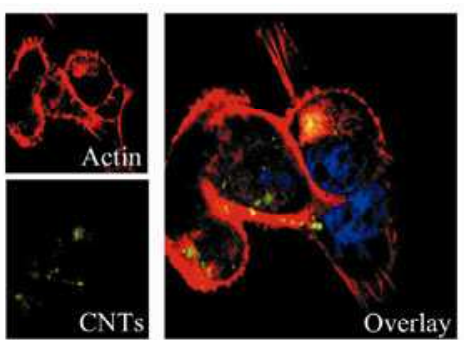

(a) Staining of Actin filaments (Phallodin)
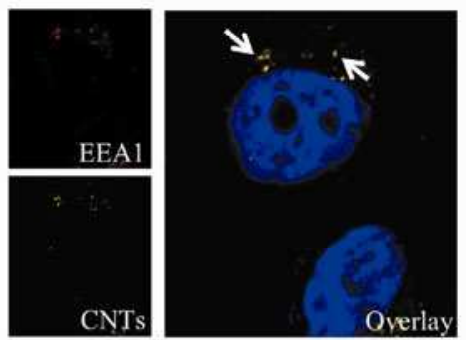

(d) Staining endosomes (EEAl)
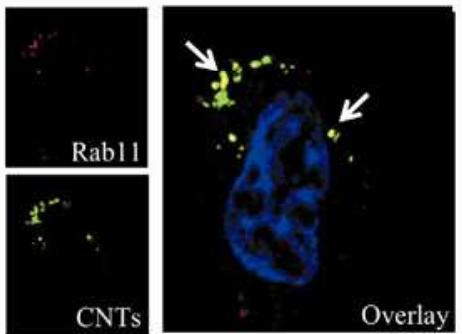

(g) Staining recycling-endosomes (Rab11)
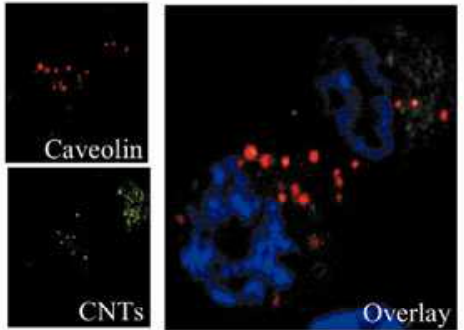

(b) Staining endosomes (caveolin)
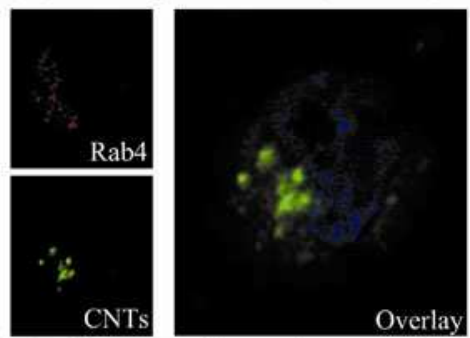

(e) Staining recycling-endosomes (Rab4)
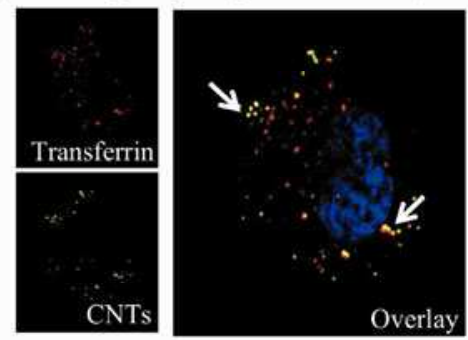

(h) Staining endosomes (Transferrin)
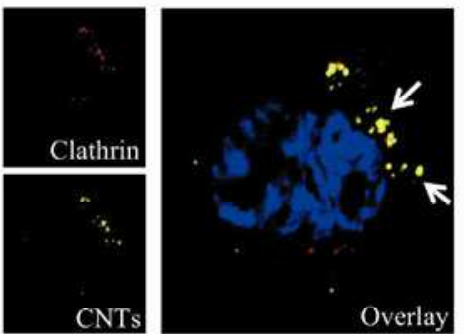

(c) Staining endosomes (clathrin)
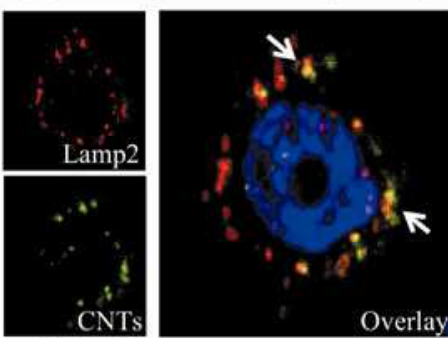

(f) Staining Lysosomes (Lamp2)
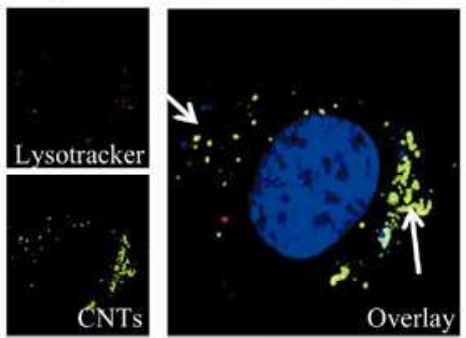

(i) Staining Lysosomes (Lysotracker)

Figure 2 Subcellular distribution of CNT complexes in PC3 cells . Cells were incubated with $30 \mu \mathrm{g} / \mathrm{mL}$ of ox DWNT-RNA-FS for 2 h. (a) Cells stained for pr esence of actin filaments (red) w ith Alexa Fluor ${ }^{\circledR} 546$ Phalloid in and with T O-PROß-3 for nuclei (bl ue) prior to being imaged for CNT complex accumulation (green). (b)-(i) Co-localization of CNT complexes (green) with antibody-specific and com partmental markers (red) in PC3 cel ls. Co-loca lization was observed for clathrin- positive vesicl es (c); EEA1-positive early endosomal vesicles (d); Lamp2-positive lysosomes (f); Rab 11-positive recycling endosomes (g); transferrin (h); and LysoTracker ${ }^{\circledR}$ red (i). Yellow colour (arrows) indicates cell compartments positive for both CNT complexes and organelle markers. Counterstaining was not observed for caveolin (b) and Rab 4 (e)

membrane. The co-localization of CNTs with this protein further confirms that they are internalized via clathrin-dependent endocytosis and that they undergo sorting in late endosomes.

Fluorescence microscopy can furthermore be used as a semi-quantitative estimate of the $\mathrm{pH}$ in endocytic structures in cell culture models by staining with $\mathrm{pH}$-sensitive dyes, such as the LysoTracker ${ }^{\circledR}$ dyes. This dye stains acidic compartments in live cells, in particular the lysosomes. Thus, in combination with LAMP2 antibody staining it provides further confirmation of the sequestration of CNT complexes in lysosomes. As demonstrated in Fig. 2(i), there is an overlap between LysoTracker® (red) and CNT complexes (green), indicating that the CNT complexes are located in an acidic compartment. A more detailed analysis including co-localization profiles of selected regions can be found in Fig. S-2 in the Electronic Supplementary Material (ESM).

It is important to note that confocal microscopy does not provide sufficient resolution to observe single nanotubes, which have been shown to traffic within cells in an entirely different fashion (bundles are mainly taken up by endocytosis, whereas single nanotubes can pierce though the membrane of the cell and also those of intracellular organelles) [15, 18]. In addition, 
cellular uptake of CNTs is strongly influenced by the type of functionalization used. While the surface charge of CNTs (i.e., carboxylated (-) and amine-terminated (+) CNTs) did not seem to have an effect on cellular uptake due to heavy protein coating leading to compensation of the surface charges [15], it has been observed that the attachment of a large molecule, for example the protein bovine serum albumin (BSA), can direct cellular uptake towards endocytosis [18].

\subsection{Effect of pathway inhibitory drugs on localization of CNT-complexes}

A systematic analysis of intracellular transport pathways is readily achieved by analysing the effects of inhibiting one or more transport processes. A widely used method for inhibiting transport is to apply a temperature block to cells [30]. Most transport processes, including clathrin-dependent internalization, will be blocked at $4{ }^{\circ} \mathrm{C}$. Endocytosis is an energydependent mechanism that is also hindered when incubations are carried out in ATP-depleted environments, as attained by incubation with $10 \mathrm{mmol} / \mathrm{L}$ sodium azide $\left(\mathrm{NaN}_{3}\right)$. In our experiments (Figs. 3(b) and $3(\mathrm{c})$ ), both incubation at $4{ }^{\circ} \mathrm{C}$ and with $\mathrm{NaN}_{3}$ resulted in inhibition of uptake of CNT complexes in PC3 cells, suggesting an energy-dependent mechanism for their internalization.

Pharmacological inhibition of cellular trafficking can be achieved with the compound LY294002, which is an inhibitor of phosphoinositide 3-kinase (PI-3 kinase). PI-3 kinases are a family of enzymes involved in signal transduction and membrane trafficking, as well as other molecular processes. Trafficking processes that are inhibited by LY294002 include translocation to the plasma membrane [33, 34], endocytosis [35, 36], endosome fusion [31], lysosomal protein sorting [37, 38], transcytosis [39], and autophagy [40]. The compound 3-methyladenine is a specific inhibitor of autophagic sequestration [41] that also inhibits PI-3 kinase. When either LY294002 or 3-methyladenine were employed in our study, we observed a blockage of membrane traffic and endosome fusion, which prevented CNT complexes from being internalized by PC3 cells (Figs. 3(d) and 3(e)).

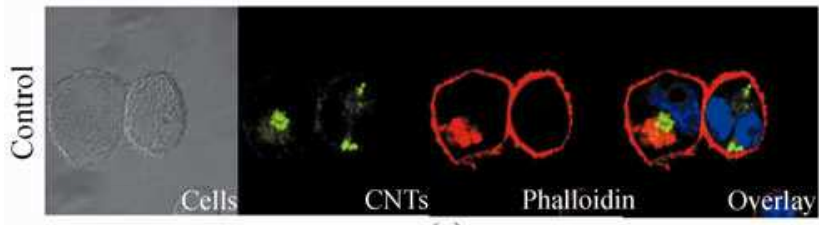

(a)

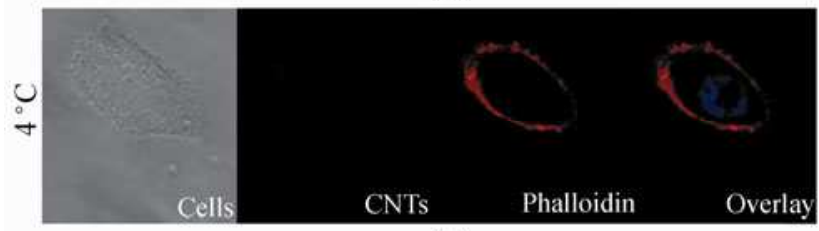

(b)

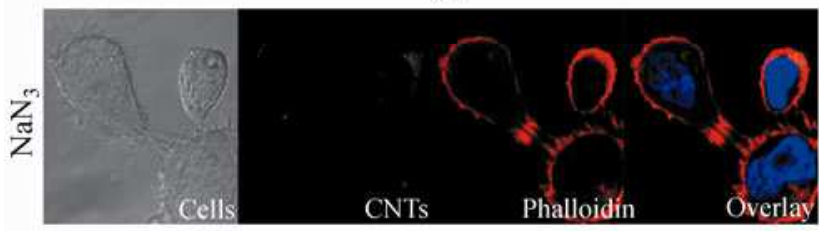

(c)

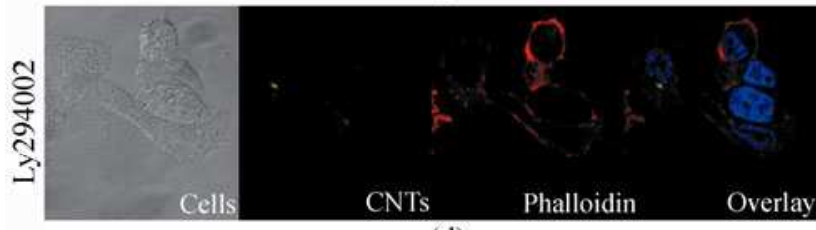

(d)

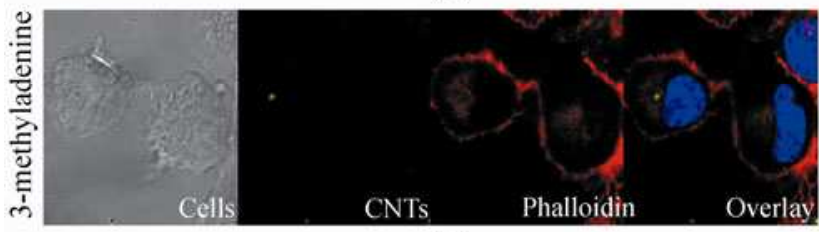

(e)

Figure 3 Effect of inh ibitory conditions for endocytic up take. Cells were expo sed to $30 \mu \mathrm{g} / \mathrm{mL}$ of oxDWNT-RNA-FS for $2 \mathrm{~h}$ and the effects of various (pre)-treatments on CNT internalization were studied (a). incubation at $4{ }^{\circ} \mathrm{C}(\mathrm{b})$; pre-incubation with sodium azide $\left(\mathrm{NaN}_{3}\right)$ (c); pre-incubation with phosphoino sitide 3-kinase inhibitor (LY294002) (d); pre-incubation with 3-methyladenine (e). Actin filaments (red) were stained with Alexa Fluor ${ }^{\circledR} 546$ Phalloidin and nuclei (blue) with TO-PRO ${ }^{\circledR}-3$

\section{Conclusions}

The objective of the present study was to elucidate the mechanism of uptake of CNTs, as well as to determine the intracellular compartments in which they localize.

From the data presented herein we propose an endocytic route for uptake and trafficking of CNT complexes (functionalized by means of oxidation and wrapping with RNA). Figure 4 schematically represents the intermediate stations of CNT complexes during 


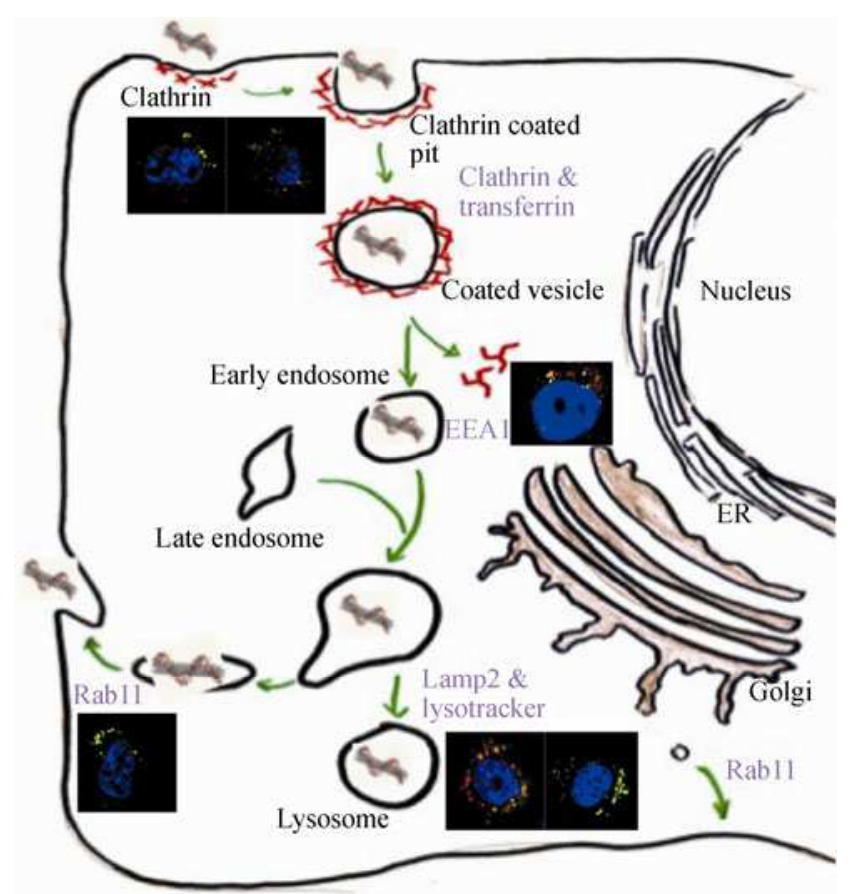

Figure 4 Proposed intracellular trafficking of CNT complexes. The internalization of oxDWNT-RNA-FS-complexes was prove $n$ to be energy-dependent as it could be blocked by incubation at $4{ }^{\circ} \mathrm{C}$ and pre-incubation with $\mathrm{NaN}_{3}$ (Figs. 3(b) and 3(c)). Additionally, incubation with PI-3 kin ase inhibitors, known to interfer e with vesicular traf ficking, led to $r$ educed in ternalization of $\mathrm{CN}$ Ts (Figs. 3(d) and 3(e)) . Co-lo calization with b oth c lathrin and transferrin prov ided evidence for clathr in-mediated endocy tosis (Figs. 2(c) and 2(h)), after which CNT complexes undergo sorting in the ear ly e ndosomes (co-loca lization wi th EEA1-Fig. 2(d)). CNT com plexes are then $\mathrm{s}$ equestrated in th e 1 ysosomes, a $\mathrm{s}$ confirmed by Lamp2 and LysoTracker ${ }^{\circledR}$ staining (Figs. 2(f) and 2(i), respectively). CNTs were also found within vesicles of the secretory pathway (Rab 11-positive vesicles), which for the first time suggests an exact route for their exocytosis (Fig. 2(g))

their passage through PC3 cells. Evidence of their intracellular localization was demonstrated by Raman spectroscopy and fluorescence spectroscopy of exposed cells. The CNT complexes were found to be endocytosed by capture in clathrin-coated vesicles as revealed by clear co-localization with both clathrin and transferrin. These results are in agreement with the work reported by Kam et al. [5], who also found evidence for clathrinmediated endocytosis as an uptake mechanism for CNTs. Molecules entering cells via endocytic pathways will rapidly experience a drop in $\mathrm{pH}$ from neutral to $\mathrm{pH}$ 5.9-6.0 in the lumen of early/recycling vesicles with further reduction from $\mathrm{pH} 6.0$ to $\mathrm{pH} 5.0$ during progression from late endosomes to lysosomes [32].
In our studies, CNT complexes were found in early endosomes as confirmed by co-localization with early endosome antigen (EEA). CNT complexes were not sorted for recycling back to the cell membrane (via fast recycling endosomes), as co-localization with Rab 4 was not observed; instead, co-localization with both LAMP2 antibody and LysoTracker ${ }^{\circledR}$ marker indicated their sequestration in lysosomes. In addition, CNT complexes were also found within Rab 11-positive vesicles of the secretory pathway.

Overall, our study brings novel findings on the uptake and traffic of CNTs in mammalian cells, allowing identification of the uptake pathway and the cellular organelles, in which CNTs localize. Additionally, exocytosis was once again confirmed with additional identification of the key organelle responsible for CNTs efflux: it is reported for the first time that the recycling endosomes from the trans-golgi network (Rab 11-positive vesicles) are responsible for extracellular extrusion of CNTs.

\section{Experimental}

\subsection{Preparation of fluorescently labelled oxidized DWNTs}

DWNTs synthesized by the CCVD (catalytic chemical vapor deposition) technique [42] were purified in concentrated nitric acid and oxidized in a mixture of nitric and sulphuric acids [43]. In the first step, $100 \mathrm{mg}$ of CNTs were dispersed in $20 \mathrm{~mL}$ of concentrated nitric acid, sonicated with a tip sonicator (MSE Soniprep 150, amplitude $8 \mu \mathrm{m}$ ) six times for $10 \mathrm{~s}$, and incubated in a water bath (Grant ultrasonic bath XB2, Farnell, UK) at $95^{\circ} \mathrm{C}$ for $2 \mathrm{~h}$. After oxidation, the acid was diluted with water and the mixture centrifuged $(10 \mathrm{~min}$ at $50000 \mathrm{~g}, 4^{\circ} \mathrm{C}$ ) (Beckman Avanti J25, Buckinghamshire, UK), followed by thorough washing with distilled water. These pre-treated CNTs were then redispersed in a 3:1 mixture of concentrated nitric and sulphuric acids and the above described process repeated. Afterwards, the oxidized CNTs were vacuum-filtered using a $0.2 \mu \mathrm{m}$ polycarbonate filter (Whatman Ltd., UK) until the eluate was clear and of neutral $\mathrm{pH}$. The filtrate was then sonicated with a tip sonicator six 
times for $10 \mathrm{~s}$ and centrifuged three times at $75000 \mathrm{~g}$ to remove large agglomerates and CNT bundles. The concentration of these dispersions was determined gravimetrically and adjusted to $100 \mu \mathrm{g} / \mathrm{mL}$ for storage in the fridge at $4{ }^{\circ} \mathrm{C}$. After oxidation, nanotubes were sterilized by autoclaving at $121{ }^{\circ} \mathrm{C}$ for $1 \mathrm{~h}$ and were maintained under sterile conditions for the duration of the experiment. In a second step, the oxDWNTs were biofunctionalized by wrapping with fluorescently labelled RNA as described below.

Biofunctionalization of oxDWNTs with RNA was achieved using ready-made fluorescently labelled RNA (Eurofins-MWG Operon), with the oligonucleotide sequence (5') CAUUCCGAGUGUCCACAUUCCGA GUGUCCA-FLU (3') (RNA-FS). The manufacturer details states that the oligonucleotide has a molecular weight of $10052 \mathrm{~g} / \mathrm{mol}, T_{\mathrm{m}}$ of $69.5^{\circ} \mathrm{C}$, GC-content of $53.3 \%$ and has been purified by high-performance liquid chromatography (HPLC). A solution of $1.0 \mathrm{mg} / \mathrm{mL}$ (prepared in sterile water) was diluted 1:5 in a solution of oxDWNTs at a concentration of $200 \mu \mathrm{g} / \mathrm{mL}$ (weight ratio CNTs/RNA 1:0.8). After that, the complexes were allowed to form by stirring for $2 \mathrm{~h}$ at room temperature $\left(\sim 21^{\circ} \mathrm{C}\right)$ in the dark. To remove unbound RNA-FS, the solution was filtered and washed several times using $100 \mathrm{kDa}$ centrifugal filters (Millipore). Finally, the oxDWNT-RNA-FS were resuspended in sterile water to a final concentration of $200 \mu \mathrm{g} / \mathrm{mL}$.

Samples were characterized by Raman spectroscopy, AFM, and TEM. Raman spectroscopy was performed for pristine DWNTs, oxDWNTs-RNA, and cells containing oxDWNT-RNA-FS, using a Renishaw inVia Raman microscope, $E_{\text {laser }}=1.59 \mathrm{eV}$ (785 nm wavelength). For AFM sample preparation, oxDWNTs were diluted with water to obtain a concentration of $10 \mu \mathrm{g} / \mathrm{mL}$. A droplet of $2 \mu \mathrm{L}$ was placed onto a freshly cleaved mica substrate $\left(1 \mathrm{~cm}^{2}\right)$ and dried in air. AFM measurements were performed using a PicoPlus instrument (Agilent Technologies, Chandler, AZ) operated in contact mode at room temperature with a lateral scan rate of $1-1.5 \mathrm{~Hz}$ at 512 lines. Data analysis was carried out using "Gwyddion 2.9", a free SPM data visualization and imaging tool released under the GNU General Public License. Samples for TEM were prepared by dilution of the sample in acetone and placing a single drop of the solution on a standard copper grid. High resolution TEM measurements were performed using a FEI Tecnai G2F20 S Twin instrument with an accelerating voltage of $200 \mathrm{kV}$.

\subsection{Cellular incubation with CNTs-complexes and compartment staining}

PC3 cells were cultured in RPMI-1640 medium supplemented with $10 \%$ FBS, 2 mmol/L Glutamax ${ }^{\mathrm{TM}}$ and $1 \%$ penicillin-streptomycin (all obtained from Invitrogen, Paisley, UK). Cells were cultured in 24-well (13 mm-well) sterile plates (Nunc, Thermo Scientific) containing glass coverslips (VWR International, Lutterworth, UK) for $24 \mathrm{~h}$ so that they were $50 \%$ confluent at the time of exposure to CNT complexes.

\subsubsection{Incubation with inhibitory drugs}

For adenosine triphosphate (ATP) depletion studies, a phosphate buffered saline (PBS) buffer solution supplemented with $10 \mathrm{mmol} / \mathrm{L}$ sodium azide $\left(\mathrm{NaN}_{3}\right)$ and $50 \mathrm{mmol} / \mathrm{L} D$-glucose was diluted as a ratio of 1:2 in complete RPMI medium and incubated with cells for $2 \mathrm{~h}$ at $37^{\circ} \mathrm{C}$, followed by incubation in a solution of CNT complexes. For inhibitory conditions with LY294002 (phosphoinositide 3-kinase inhibitor) and 3-methyladenine (inhibitor of autophagic sequestration), cells were incubated overnight with $10 \mu \mathrm{mol} / \mathrm{L}$ of drug before addition of the CNT complexes.

\subsubsection{Incubation with CNT-complexes}

PC3 cells growing in 24-well plates were incubated with $30 \mu \mathrm{g} / \mathrm{mL}$ CNT complexes diluted in complete RPMI medium. After incubation for $2 \mathrm{~h}$, cells were washed twice with sterile PBS (Invitrogen, Paisley, UK) and fresh medium added for $5 \mathrm{~min}$. Cells were again washed with sterile PBS and treated for $10 \mathrm{~min}$ with CellScrub (Genlantis, San Diego, USA) washing buffer to remove all extracellular CNT complexes. Finally, cells were washed twice more with sterile PBS.

\subsubsection{Cell fixation}

To prevent morphological changes and inhibit further natural cellular transport, cells were fixed with $4 \%$ $(w / v)$ paraformaldehyde (Sigma Aldrich, Poole, UK) solution in PBS for $1 \mathrm{~h}$ at room temperature. Then cells 
were washed once more with sterile PBS and treated with $0.1 \%$ v/v Triton X-100 (Sigma Aldrich, Poole, UK) in PBS to allow permeabilization of cell membranes.

4.2.4 Compartment staining (using phalloidin, TOPRO®-3, LysoTracker ${ }^{\circledR}$ red and transferrin)

Cell membrane-associated actin filaments were stained using phallotoxins (Alexa Fluor ${ }^{\circledR} 555$ Phalloidinemission $565 \mathrm{~nm}$ ) with a final concentration of $0.044 \mu \mathrm{mol} / \mathrm{L}$. Transferrin conjugates (Alexa Fluor ${ }^{\circledR}$ $546-$ emission $573 \mathrm{~nm}$ ) at a concentration of $20 \mu \mathrm{g} / \mathrm{mL}$ were applied to stain endosomes associated with clathrin-dependent endocytosis, and acidic cell compartments (lysosomes) were stained using LysoTracker ${ }^{\circledR}$ Red DND-99 (emission $590 \mathrm{~nm}$ ) at a final concentration of $1 \mu \mathrm{mol} / \mathrm{L}$. All agents were diluted from freshly made stock solutions in $0.5 \%$ bovine serum albumin (BSA; Sigma Aldrich) in sterile PBS and applied to cells after fixation for a period of $15 \mathrm{~min}$. Cells were then washed three times with PBS and finally, To-Pro ${ }^{\circledR}-3$ (emission $661 \mathrm{~nm}$ ), a monomeric cyanine nucleic acid stain, was applied in order to visualize the cell nuclei in all samples. It was employed as the final step of the immunocytochemistry using a concentration of $0.1 \mu \mathrm{mol} / \mathrm{L}$ in PBS (all reagents from Invitrogen-Molecular Probes Corporation, unless stated otherwise).

\subsubsection{Immunostaining}

Subsequent to cell fixation and permeabilization, cells were incubated for $90 \mathrm{~min}$ with primary antibodies (Santa Cruz Biotechnology, Inc; supplied by Insight Biotechnology; Harrow, UK) diluted in PBS containing $0.5 \%$ BSA, as described in Table 1. Cells were then washed three times with PBS and incubated for $1 \mathrm{~h}$ with fluorescent secondary antibody (Alexa Fluor ${ }^{\circledR}$ 546 from Invitrogen) diluted 1:100 in $0.5 \%$ BSA in PBS, followed by three $5 \mathrm{~min}$ washes in PBS. After immunostaining, cells were also stained with To-Pro ${ }^{\circledR}-3$ as described (above).

\subsubsection{Mounting glass-slides and microscopy}

Following the final step for all samples, in which nucleic acids were stained with To-Pro ${ }^{\circledR}-3$, coverslips were removed from the 24 -well plate using fine forceps and were then held vertically against tissue to remove
Table 1 Immunostaining. Primar y antibodies emplo yed an $\mathrm{d}$ respective secondary antibodies

\begin{tabular}{lc}
\hline \multicolumn{1}{c}{ Primary antibody } & $\begin{array}{c}\text { Dilution factor for } \\
\text { primary antibody }\end{array}$ \\
$\begin{array}{l}\text { Secondary } \\
\text { antibody }\end{array}$ \\
\hline Clathrin HC (H-300): sc-9069 & $1: 100$ Anti-rabbit \\
Caveolin-1 (N20): sc-894 & $1: 200$ Anti-rabbit \\
$\begin{array}{l}\text { Early endosome antigen (EEA1) } \\
\text { (C15): sc-6414 }\end{array}$ & $1: 500$ Anti-goat \\
$\begin{array}{l}\text { Lysosome-associated me mbrane } \\
\text { proteins (Lamp 2) (H4B4): sc- } \\
\text { 18822 }\end{array}$ & $1: 2000$ Anti-mouse \\
$\begin{array}{l}\text { Ras-related superfamily - Rab } \\
\text { 4/14 (FL-213): sc28569 }\end{array}$ & $1: 200$ Anti-rabbit \\
$\begin{array}{l}\text { Ras-related superfamily - Rab } \\
\text { 11 (H87): sc-9020 }\end{array}$ & $1: 80$ Anti-rabbit \\
\hline
\end{tabular}

excess liquid. A small drop of VECTASHIELD ${ }^{\circledR}$ Mounting Medium (Vector Laboratories, UK) was placed on a glass slide and the coverslip, cells facing down, was positioned on top of the Vectashield drop. After removing the excess liquid, coverslips were sealed using a standard commercially available nail lacquer and allowed to dry.

Images were captured using $63 x$ magnification with a Zeiss LSM 510 inverted confocal microscope and analysed using LSM 510 META software (Zeiss).

\section{Acknowledgements}

This work has been performed in the framework of the FP6 Marie Curie Research Training Network CARBIO (Multifunctional carbon nanotubes for biomedical applications) funded by the European Union.

Electronic Supplementary Material: Supplementary material with further details on time-series analysis of fluorescently labelled RNA-wrapped oxidized DWNTs in cells and a plot profiles of antibody/CNTs is available in the online version of this article at http://dx.doi.org/10.1007/s12274-012-0202-9 and may be accessed free of charge.

\section{References}

[1] Pantarotto, D.; Br iand, J . M .; P rato, M.; B ianco, A . Translocation of bioactive peptides across cell membranes by carbon nanotubes. Chem. Commun. 2004, 16-17. 
[2] Kostarelos, K.; L acerda1, L.; P astorin, G.; W u, W .; Wieckowski, S.; Luangsivilay, J.; Godefroy, S.; Pantarotto, D.; Br iand, J. P.; Mul ler, S.; e t al . Ce llular upt ake of functionalized carbon nan otubes is indepen dent of functional group and cell type. Nat. Nanotechnol. 2007, 2, 108-113.

[3] Lacerda, L.; Raffa, S.; Prato, M.; Bianco, A.; Kostarelos, K. Cell-penetrating CNTs for d elivery of ther apeutics. Nano Today 2007, 2, 38-43.

[4] Neves, V.; Heister, E.; Costa, S.; Tîlmaciu, C.; BorowiakPalen, E.; Giusca1, C. E.; Flahaut, E.; Soula, B.; Coley, H. M.; McFadden, J.; et al . Uptake and Release of Double-Walled Carbon Nanotubes by Mammalian Cells. Adv. Funct. Mater. 2010, 20, 3272-3279.

[5] Kam, N. W. S. ; Liu, Z.; Dai, H. J . Carb on nanotubes as intracellular transporters for proteins and DNA: An investigation of the uptake mechanism and pathway. Angew Chem. Int. Ed. 2006, 45, 577-581.

[6] Jin, H. ; Heller, D. A. ; S harma, R.; Strano, M. S. Sizedependent cellular uptake and expulsion of sin gle-walled carbon nanotubes: Single particle tracking and a generic uptake model for nanoparticles. ACS Nano 2009, 3, 149-158.

[7] Wei, M. L.; Bonzelius, R.; Scully, R. M.; Kelly, R. B.; Herman, G. A. GLUT4 and transferrin receptor are differentially sorted along the endocytic p athway in CHO cells . J. Cell Biol. 1998, 140, 565-575.

[8] Connolly, C. N.; Futter, C. E,; Gibson, A.; Hopkins, C. R.; Cutler, D. F. Transport into and out of the Golgi complex studied by transfecting cells with cDNAs encoding horseradish peroxidase. J. Cell Biol. 1994, 127, 641-652.

[9] Yamashiro, D. J.; Tycko, B.; Fluss, S. R .; Maxfield, F. R . Segregation of transferrin to a mildly acidic ( $\mathrm{pH}$ 6.5) $\mathrm{p}$ araGolgi compartment in the recycling pathway. Cell 1984, 37, 789-800.

[10] Mullock, B. M.; Bright, N. A.; Fearon, C. W.; Gray, S. R.; Luzio, J. Fu sion of ly sosomes with late endoso mes produces a $\mathrm{h}$ ybrid org anelle of in termediate d ensity and is NSF dependent. J. Cell Biol. 1998, 140, 591-601.

[11] Bucci, C.; Parton, R. G. ; Mather, I. H .; Stunnenberg, H.; Simons, K.; Hoflack, B.; Zerial, M. The small GTPase rab5 functions as a regulator $y$ factor in the early endocytic pathway. Cell 1992, 70, 715-728.

[12] Ren, M.; Xu, G.; Zeng, J.; L emos-Chiarandini, C . D. ; Adesnik, M.; Sabatini, D. D. Hydrolysis of GTP on rab11 is required for the dir ect d elivery of transferrin from the pericentriolar recycling compartment to the cell surface but not from sorting endosomes. Proc. Natl. Acad. Sci. U. S. A., 1998, 95, 6187-6192.

[13] Jin, H.; Heller D. A.; Strano, M. S. Single-particle tracking of endocytosis and exocytosis of single-walled carbon nanotubes in NIH-3T3 cells. Nano Lett. 2008, 8, 1577-1585.

[14] Pantarotto, D.; Singh, R.; McCarthy, D.; Erhardt, M.; B riand, J. P.; Prato, M.; Kostarelos, K.; Bianco, A. F unctionalized carbon nanotubes for plasmid DNA gene deliver y. Angew Chem. Int. Ed. 2004, 43, 5242-5246.

[15] Mu, Q.; Broughton, D. L.; Yan, B. Endosomal leakage and nuclear translocation of mu ltiwalled carbon nanotubes: developing a model for cell up take. Nano Lett. 2009, 9, 4370-4375.

[16] Yehia, H. N.; Draper, R. K.; Mikoryak, C.; Walker, E. K.; Bajaj, P.; Musselman, I. H.; Daigrepont, M. C. Dieckmann, G. R.; Pantano, P. Single-walled carbon nanotube interactions with HeLa cells. J. Nanobiotechnol. 2007, 5, 3155-3163.

[17] Lacerda, L.; Pastorin, G.; Gathercole, D.; Buddle, J.; Prato, M.; Bi anco, A. ; Kos tarelos, K. Intracellular tra fficking of carbon nanotub es b y confo cal laser scanning microscop y. Adv. Mater. 2007, 19, 1780-1784.

[18] Zhou, F.; Xing, D.; Wu, B.; Wu, S .; Ou, Z.; Chen , W. R. New insights of transmembranal mechanism and subcellular localization of noncovalently modified single-walled carbon nanotubes. Nano Lett. 2010, 10, 1677-1681.

[19] Saito, R. ; Dre sselhaus, G.; Dre ssehaus, M. S. Physical Properties of Carbon Nanotubes; London: Imperial College Press, 1998.

[20] Strano, M . S.; Doorn , S. K.; Haroz, E. H.; Kittrell, C.; Hauge, R. H.; Smalley, R. E. Assignment of (n, m) Raman and optical features of metallic single-walled carbon nanotubes. Nano Lett. 2003, 3, 1091-1096.

[21] Doorn, S. K.; Heller, D. A.; Barone, P. W.; Usrey , M. L.; Strano, M. S . Resonan t R aman excitation profiles of individually dis persed single walled carbon nanotubes in solution. Appl. Phys. A 2004, 78, 1147-1155.

[22] Heister, E.; Lamprecht, C.; Neves, V.; Tîlmaciu, C.; Datas, L.; Fla haut, E.; Soula, B.; Hi nterdorfer, P.; Col ey, H. M. ; Silva, S. R. P.; et al. Higher dispersion efficacy of functionalized carbon nanotubes in chemical and biological environments. ACS Nano 2010, 4, 2615-2626.

[23] Bartholomeusz, G.; Cherukuri, P.; Kingston, J.; Cognet, L.; Lemos, R.; L eeuw, T. K. ; Gumbi ner-Russo, L.; We isman R. B .; Powis, G . In vivo th erapeutic sile ncing of hypoxiainducible factor 1 alpha (HIF -1alpha) using sin gle-walled carbon nanotubes noncovalently coated with siR NA. Nano Res 2009, 2, 279-291.

[24] Wu, Y.; Phillips, J. A.; Liu, H.; Yang, R.; Tan, W. Carbon nanotubes protect DNA strands during cellular delivery. ACS Nano 2008, 2, 2023-2028.

[25] Aniento, F.; Emans, N.; Griffiths, G.; Gruenberg, J. Cytoplasmic dynein-dependent vesicular tr ansport from ea rly to 1 ate endosomes. J. Cell Biol. 1993, 123, 1373-1387. 
[26] Parton, R. G.; Sim ons, K. The m ultiple faces of c aveolae. Nat. Rev. Mol. Cell Biol. 2007, 8, 185-194.

[27] Luzio, J. P .; Mullock, B. M.; Pryor, P. R.; Lindsay, M. R .; James, D. E.; Piper, R. C. Relationship between endosomes and lysosomes. Biochem. Soc. Trans. 2001, 29, 476-480.

[28] Saftig, P.; Klumperman, J. Lysosome biogenesis and lysosomal membrane proteins: Traff icking meets function . Nat. Rev. Mol. Cell Biol. 2009, 10, 623-635.

[29] Ghosh, R. N.; Mallet, W. G.; Soe, T. T.; McGraw, T. E.; Maxfield, F. R. An endocytosed TGN38 chimeric protein is delivered to the TGN after trafficking through the endocytic recycling com partment in CHO cells. J. Cell Biol. 1998, 142, 923-936.

[30] Saraste, J.; Palade, G. E.; Farquhar, M. G. Temperatur esensitive steps in the transport of secretory proteins through the Golgi complex in exocrine pancreatic cells. Proc. Natl. Acad. Sci. U. S. A. 1986, 83, 6425-6429.

[31] Jones, A. T.; Clague, M. J. Phosphatid ylinositol 3-kin ase activity is required for early endosome fusion. Biochem. $J$. 1995, 311, 31-34.

[32] Maxfield, F. R.; McGraw, T. E. Endo cytic recy cling. Nat. Rev. Mol. Cell Biol. 2004, 5, 121-132.

[33] Quon, M. J.; Chen, H.; Ing, B. L.; Liu, M. L.; Zarnowski, M. J.; Yonezawa, K.; Kasuga, M.; Cushman, S. W.; Taylor, S. I. Roles of 1-phosphatidylinositol 3-kinase and ras in regulating translocation of GLUT4 in transfected rat adipose cells. Mol. Cell. Biol. 1995, 15, 5403-5411.

[34] Clarke, J. F.; Young, P. W.; Yonezawa, K.; Kasug a, M.; Holman, G. D. Inhibition of the translo cation of GLUT1 and GLUT4 in 3T3-L1 cells by the phosphatid ylinositol 3-kinase inhibito r, wortmannin. Biochem. J. 1994, 300, 631-635.

[35] Clague, M. J.; Thorpe, C.; Jones, A. T. Phosphatidylinositol 3-kinase regulation of fl uid phas e endocytosis. FEBS Lett.
1995, 367, 272-274.

[36] Li, G.; D'Souza-Schorey, C.; Barbieri, M. A.; Roberts, R. L.; Klippel, A. ; W illiams, L. T .; Stahl P. D. Evidence for phosphatidylinositol 3-kin ase as a regu lator of endocy tosis via activation of Rab5. Proc. Natl. Acad. Sci. U. S. A. 1995, 92, 10207-10211.

[37] Brown, W . J .; DeWald, D. B. ; E mr, S. D. ; Pl utner, H. ; Balch, W. E. R ole for phosphatidylinositol 3-kinase in the sorting and transport of newly synthesized lysosomal enzymes in mammalian cells. J. Cell Biol. 1995, 130, 781-796.

[38] Davidson, H. W. Wort mannin causes mistargeting of procathepsin D . evidence for the invo lvement of a phosphatidylinositol 3-kinase in vesicular tr ansport to lysosomes. J. Cell Biol. 1995, 130, 797-805.

[39] Cardone, M.; Mostov, K. Wortmannin inhibits tr anscytosis of dimeric $\operatorname{IgA}$ by the polymeric immunoglobulin receptor. FEBS Lett. 1995, 376, 74-76.

[40] Blommaart, E. F. C.; Krause, U.; Schellens, J. P. M.; VreelingSindelarova, H .; Meijer, A. J. The phosphatid ylinositol 3-kinase inhib itors wort mannin and LY29400 2 inhib it autophagy in isolated rat hepatocytes. Eur. J. Biochem. 1997, 243, 240-246.

[41] Seglen, P. O.; Gordon, P . B. 3-M ethyladenine: specific inhibitor of autophagic/lysosomal protein degr adation in isolated rat hep atocytes. Proc. Natl. Acad. Sci. U. S. A. 1982, 79, 1889-1892.

[42] Flahaut, E.; Bacsa, R.; Peigney, A.; Laurent, C. Gram-scale CCVD synthesis of double-walled carbon nanotubes. Chem. Commun. 2003, 1442-1443.

[43] Heister, E.; Nevesa, V.; Tîlmaciub, C.; Lipertc, K.; Beltrána, V. S.; Coleya, H. M.; Silvad, S. R. P.; McFaddena, J. Triple functionalisation of single-w alled carbon nanotubes with doxorubicin, a monoclonal antibody, and a fluorescent marker for targeted cancer therapy. Carbon 2009, 47, 2152-2160. 